\title{
STUDI INQUIRY LEARNING PADA MATAPELAJARAN IPA DI SEKOLAH DASAR
}

\author{
Miranti Widi Andriani \\ STKIP PGRI Bangkalan \\ mirantiwidi@stkippgri-bkl.ac.id
}

\begin{abstract}
Abstrak:
Metode pembelajaran adalah cara atau teknik yang dipakai guru untuk mengelola pembelajaran sehingga sehingga tujuan belajar yaitu kemampuan akhir yang diharapkan dapat tercapai secara efektif dan efisien. Inquiry learning (pembelajaran inkuiri/menemukan) adalah salah satu metode yang dapat digunakan oleh guru. Tujuan penelitian ini adalah mendeskripsikan tindak pembelajaran inkuiri pada matapelajaran IPA kelas V Sekolah Dasar. Penelitian ini menggunakan pendekatan kualitatif, jenis penelitian studi kasus untuk menjawab pertanyaan penelitian. Peneliti sebagai alat pengumpul data utama. Pengumpulan data melalui wawancara mendalam (in-depth interview), observasi tidak terstruktur dan dokumen. Beberapa temuan penelitian menunjukkan inquiry learning yang dilakukan oleh guru pada matapelajaran IPA antara lain: guru memulai pembelajaran dengan pertanyaan; guru mengarahkan siswa pada pemahaman yang mendalam; guru memberikan umpan balik; guru memberikan tugas proyek; guru membentuk kelompok dalam pembelajaran.
\end{abstract}

Kata Kunci: studi kasus, pembelajaran inkuiri, sekolah dasar

\section{Pendahuluan}

Kurikulum 2013

merupakan kurikulum terbaru yang menjadi dasar pembelajaran di indonesia. Pembelajaran pada K13 menggunakan pendekatan saintifik, merupakan pengorganisasian pengalaman belajar. Pengalaman tersebut dikemas dalam 5M (mengamati; menanya; mengumpulkan informasi/mencoba;

menalar/mengasosiasi; dan mengkomunikasikan). Hai ini dapat dimaknai bahwa K13 mendorong siswa lebih aktif dalam pembelajaran baik dalam mengumpulkan informasi hingga menyimpulkan materi pelajaran dengan panduan guru.

Pendekatan pembelajaran salah satunya pendekatan saintifik merupakan cara guru mengelola situasi belajar di dalam kelas sehingga tercipta suasana pembelajaran yang memungkinkan terjadinya proses pembelajaran yang efektif. Mengelola situasi belajar yang dilakukan oleh guru adalah sebagai tahapan untuk mencapai kompetensi yang diharapkan dari peserta didik. Oleh karena itu, pendekatan pembelajaran disesuaikan dengan kebutuhan kurikulum dan capaian pembelajaran.

Penerapan pendekatan saintifik, memiliki keunikan bahwa materi pembelajaran dirumuskan berdasarkan pada fakta atau dapat dijelaskan dengan penalaran. Keunikan ini mendorong siswa berpikir secara kritis, belajar menganalisis, dan memecahkan masalah berdasarkan 
temuan pengamatan yang telah dilakukan. Maka pendekatan saintifik sangat menuntut siswa berperan secara aktif dalam pembelajaran guna menemukan pemahaman baru dari materi yang disuguhkan.

Proses pembelajaran meliputi tiga ranah, yaitu: sikap, pengetahuan, dan keterampilan. Hasil belajar diharapkan membuat siswa lebih produktif, kreatif, inovatif, santun bersikap, berketerampilan, dan berpengetahuan yang terintegrasi dalam capaian pembelajaran. Tidak hanya itu, siswa diharapkan dapat memahami materi baik apa, mengapa dan bagaimana penjelasan materi tersebut. Sehingga siswa dapat memperoleh hasil akhir yang baik dari segi kemampuan, kecakapan dan pengetahuan.

Peran guru selanjutnya adalah menentukan metode yang akan digunakan dalam pembelajaran. Metode yang menarik akan membuat siswa bersemangat dalam belajar. Imbas dari bersemangatnya siswa terhadap pelajaran diharapkan dapat meningkatkan minat atau keingintahuan siswa terhadap materi ajar. Dapat disimpulkan metode pembelajaran adalah cara atau teknik yang dipakai guru untuk mengelola pembelajaran sehingga sehingga tujuan belajar yaitu kemampuan akhir yang diharapkan dapat tercapai secara efektif dan efisien.

Inquiry learning (pembelajaran inkuiri/menemukan) adalah salah satu metode yang dapat digunakan oleh guru. Secara garis besar pembelajaran inkuiri adalah pendekatan pedagogis yang mengajak siswa untuk mengeksplorasi materi pelajaran dengan menyelidiki, dan menjawab pertanyaan. Siswa dihadapkan pada materi yang dikemas sebagai pertanyaan. Hal ini mendorong siswa menjadi aktif dan terampil dalam penelitian sehingga meningkatkan pemahaman siswa terhadap materi.

Penjelasan diatas dapat dimaknai pendekatan saintifik dan metode inkuiri memiliki persamaan pandangan mengenai keaktifan siswa. Keduanya juga membutuhkan peran aktif dari siswa dan dorongan penuh dari guru agar siswa berproses dalam belajar. Sama halnya dengan pendekatam saintifik, metode inkuiri berfokus bagaimana siswa melalui proses belajar yang menyenangkan dengan tantangan dari materi yang harus dipecahkan. Siswa perlu melakukan pengamatan untuk menemukan bukti yang dapat menguatkan pengetahuan barunya.

Metode pembelajaran inkuiri dirasa tepat untuk digunakan dalam pembelajaran IPA. Metode ilmiah mendorong siswa mengkaji fenomena dengan menyeluruh untuk dapat merumuskan kesimpulan dan pemahaman. Matapelajaran IPA dengan metode pembelajaran inkuiri mengarahkan siswa mencari buktibukti dengan pengamatan dari objek yang dapat diobservasi, empiris, dan terukur dengan prinsip-prinsip penalaran yang spesifik.

Pertanyaan penelitian yang muncul adalah pada K13 yang menggunakan pendekatan saintifik, apakah prinsip-prinsip metode pembelajaran inkuiri dapat diamati. Persamaan antara pendekatan saintifik yang mendorong siswa berpikir secara kritis dengan pembelajaran inkuiri yang mengajak siswa untuk mengeksplorasi materi pelajaran dengan menyelidiki. Hal yang menarik untuk ditelaah adalah mendeskripsikan prinsip-prinsip pembelajaran inkuiri dalam pembelajaran.

Penelitian ini dilaksanakan untuk meneliti pembelajaran inkuiri yang dilakukan guru SD pada matapelajaran 
IPA. Tujuan penelitian ini adalah mendeskripsikan tindak pembelajaran inkuiri pada matapelajaran IPA kelas V SDN Kemayoran 1 Bangkalan.

\section{Metode Penelitian}

Penelitian ini menggunakan pendekatan kualitatif, jenis penelitian studi kasus untuk menjawab pertanyaan di atas. Peneliti sebagai alat pengumpul data utama dengan melakukan wawancara mendalam pada subjek penelitian. Oleh karena itu, kehadiran peneliti di lokasi penelitian mutlak diperlukan sehingga peneliti harus menciptakan hubungan yang baik dengan subjek penelitian, baik sejak awal penelitian, selama penelitian, maupun sesudah penelitian. Data penelitian ini adalah tindak pembelajaran inkuiri pada matapelajaran IPA kelas V SDN Kemayoran 1 Bangkalan. Teknik pengumpulan data yang digunakan antara lain

A. Peneliti mengumpulkan data melalui wawancara mendalam (indepth interview). Penelitian ini menggunakan wawancara terstruktur dengan menggunakan pedoman wawancara yang telah disusun sebelum pengumpulan data. Peneliti mewawancarai guru dengan mengajukan sejumlah pertanyaan yang dikembangkan dari fokus penelitian, yaitu: deskripsi tindak pendekatan konstruktivisme dalam pembelajaran oleh guru sebagai pembimbing.

B. Teknik pengumpulan data dengan observasi tidak terstruktur dilakukan dengan memasukkan frasa singkat atau pertanyaan mengidentifikasi jenis-jenis tindakan, fitur pengaturan, atau interaksi sesuai fokus penelitian. Beberapa objek yang diobservasi peneliti adalah segala sesuatu mengenai profil sekolah, baik peraturan sekolah, kompetensi wali kelas, fasilitas pendukung didalamnya, interaksi di lingkungan sekolah (antar siswa maupun siswa dengan guru).

Data observasi dimasukkan ke dalam catatan lapangan. Hal ini agar dapat mengontrol bias pengamat. Deskriptif catatan lapangan meliputi informasi berikut: Waktu, tanggal, lokasi, dan durasi pengamatan, deskripsi subjek, interaksi subjek, kegiatan subjek, dan percakapan verbatim atau kutipan langsung subjek. Catatan lapangan dibuat berdasarkan format Lodico dkk. (2006) berikut ini: 


\section{CATATAN LAPANGAN}

Tanggal pengamatan :

Waktu pengamatan

Setting/tempat

Subjek

Pengamat

ini juga dapat disebut sebagai pembelajaran berbasis masalah. Siswa menjadi pusat dan harus aktif dalam pembelajaran agar dapat terampil melakukan penelitian, pengamatan, menganalisis dan membuat kesimpulan materi. Pembelajaran \begin{tabular}{l|l|l}
\hline Subjek & Observasi inkuiriefidhkis pada penciptaan ruang \\
\hline & $\ldots \ldots \ldots \ldots \ldots \ldots \ldots \ldots$.
\end{tabular} terlibat. langsung.dalam. pembelajaran. Pada ... penerapann.y. pembelajaran inkuiri...dapat....digunakan dalam berbagai matapelajaran yang menuntut siswa...menemukan ...sendiri materi pelajaran..secara..aktif...Hal ini tentu tidak. dibatasi.hanya. untuk pelajaran sains seperti IPA dan matematika

Format Catatan Lapangan (Lodico dkk., 2006:120)

C. Teknik pengumpulan data melalui dokumen juga dilakukan oleh peneliti. Teknik ini berguna untuk memperoleh data yang tidak dapat digali yang dapat diperoleh dari arsip dan dokumen sekolah: yaitu Rancangan Pelaksanaan Pembelajaran (RPP) dan jadwal kegiatan di dalam kelas.

Triangulasi sumber data dilakukan dengan pengecekan data hasil wawancara kepada subjek penelitian, pengecekan data hasil wawancara kepada ahli, dan memeriksa pengaruh peneliti dalam paparan data dan temuan penelitian diterapkan untuk mengecek keabsahan data.

\section{Hasil dan Pembahasan}

Inquiry learning adalah pendekatan pedagogis yang mengajak siswa untuk mengeksplorasi materi pelajaran dengan menyelidiki dan menjawab pertanyaan. Pembelajaran namun juga dapat diterapkan pada pelajaran seni dan sastra.

Peran guru sangat berbeda dari metode pembelajaran konvensional. Pembelajaran inkuiri menuntut guru tidak hanya memberikan instruksi langsung kepada siswa, tetapi juga membantu siswa membuat pertanyaan terkait materi yang siswa pelajari serta mengikuti jalannya pengamatan yang dilakukan siswa. Hal ini sering disalahartikan bahwa guru tidak harus melakukan apapun dalam pembelajaran. Warner \& Myers (2011) menjabarkan saat menggunakan pelajaran berbasis inkuiri, guru bertanggung jawab untuk: a) memulai proses pembelajaran, b) mendorong siswa mengungkapkan pendapat, c) membimbing masa peralihan dari kelompok-kelompok kecil menuju diskusi kelas, d) menjadi penengah dan membantu meluruskan kesalahpahaman yang berkembang tentang pemahaman siswa terhadap materi, e) mencontohkan prosedur ilmiah serta sikap, dan f) memanfaatkan pengalaman siswa untuk membentuk pengetahuan baru.

$$
\text { Inquiry }
$$

learning mengakomodasi kebutuhan siswa 
untuk berpikir kritis. Kebutuhan ini akan membuat siswa tidak hanya pasif menerima materi dari guru namun lebih aktif untuk mengembangkan keterampilan untuk memperoleh pengetahuan tentang materi yang diberikan. Siswa dapat menghubungkan materi pelajaran dengan kehidupan nyata. Hal ini juga dijelaskan Mazzulla (2011) bahwa pembelajaran berbasis inkuiri adalah proses yang memungkinkan guru dan siswa untuk mengajukan pertanyaan tentang topik pada meteri pelajaran. Pertanyaan yang diajukan adalah menstimulasi cara pikir yang memungkinkan siswa mengembangkan dan menggunakan keterampilan berpikir kritis. Tujuan utama pembelajaran inkuiri adalah untuk meningkatkan pengetahuan siswa menjadi pemahaman yang mendalam.

Beberapa temuan penelitian menunjukkan inquiry learning yang dilakukan oleh guru pada matapelajaran IPA antara lain: guru memulai pembelajaran dengan pertanyaan; guru mengarahkan siswa pada pemahaman yang mendalam; guru memberikan umpan balik; guru memberikan tugas proyek; guru membentuk kelompok dalam pembelajaran.

\section{Guru Memulai Pembelajaran dengan Pertanyaan}

Pembelajaran biasanya dimulai dengan sebuah pertanyaan pembuka yang memancing rasa ingin tahu siswa dan atau kekaguman siswa akan suatu fenomena. Tentunya pertanyaan, masalah atau eksplorasi yang memiliki arti bagi siswa. Pembelajaran inkuiri berangkat dari masalah sehingga membentuk pertanyaan, selanjutnya dilakukan eksplorasi materi sehingga siswa dapat menghimpun pengetahuan seputar topik yang dipelajari. Pembaharuan penelitian yang dilakukan Warner \& Myers (2011) menjelaskan dalam pembelajaran inkuiri guru memainkan peran penting dalam mengadaptasikan pertanyaan sebagai awal dari proses pembelajaran untuk mengetahui tingkat pengetahuan dan kemampuan siswa. Guru mengadaptasi pertanyaan sebagai bentuk persiapan yang harus dilakukan guru, tentunya guru mengembangkan pertanyaan penting sesuai materi.

Temuan penelitian menunjukkan siswa diberi kesempatan untuk bertanya. Pertanyaan ini mengarahkan siswa padahal yang harus dipecahkan. Siswa dituntut untuk melakukan beberapa langkah seperti pengamatan, pencatatan hasil pengamatan dan menganalisis serta menyimpulkan kemudian memaparkan hasil pengamatan di depan kelas. Hal ini sesuai dengan enam tahapan siklus pengamatan dan menemukan yang ditulis Llewellyn (dalam Warner \& Myers, 2011) yaitu: 1) Inkuisisi (menyatakan pertanyaan untuk diselidiki seperti "bagaimana jika" atau "saya bertanya-tanya"), 2) Akuisisi (memikirkan kemungkinan prosedur), 3) Anggapan (mengidentifikasi pertanyaan untuk diuji "saya pikir"), 4) Implementasi (merancang dan membawa sebuah rencana), 5) Penjumlahan (mengumpulkan bukti dan menarik kesimpulan), 6 Pameran (berbagi dan komunikasi).

\section{Guru Mengarahkan Siswa Pada Pemahaman yang Mendalam}

Studi inkuiri mengarahkan siswa untuk membangun pengetahuan yang mengarah pada pemahaman yang mendalam. Guru berkomitmen untuk memberikan pengalaman yang luas 
dengan mendorong pemikiran dan rasa ingin tahu siswa. Temuan ini menunjukkan bahwa guru dalam pembelajaran inkuiri mendorong siswa untuk mengembangkan pola pikir menuju pencarian fakta dari pengamatan sebagai bukti. Bukti ini mengarah pada apa dan bagaimana sesuatu terjadi, serta mengapa dan apa dampaknya.

Komitmen ini ditunjukkan guru dengan merencanakan rangkaian pertanyaan yang dibuat secara teliti sesuai materi. Guru juga mendampingi beberapa pengamatan yang dilakukan siswa yang terbentuk dalam kelompok pada saat yang bersamaan. Peran guru sebagai fasilitator agar siswa dapat menemukan pemahaman terhadap topik. Sebagai fasilitatot guru menanggapi siswa dengan mengulang dan mengutip apa yang siswa katakan. Tujuannya adalah guru membuka celah agar siswa dapat berpikir tentang prosedur apa yang harus dilakukan dengan pertanyaannya. Warner \& Myers (2011) Siswa harus merancang kegiatan yang memungkinkan siswa untuk menemukan atau memperoleh pengalaman yang diperlukan untuk dasar pelajaran.

\section{Guru Memberikan Umpan Balik}

Guru selalu menilai kemajuan masing-masing siswa baik pada saat melakukan pengamatan hingga menyimpulkan temuan dari pengamatan. Guru memberikan umpan balik deskriptif tepat waktu dan menggunakan berbagai metode, termasuk evaluasi teman dan evaluasi diri. Hal ini memberikan peluang bagi siswa untuk merefleksikan pembelajaran mereka menggunakan kriteria yang jelas. Dengan umpan balik terhadap pengamatan yang dilakukan oleh siswa, siswa dapat menetapkan tujuan pengamatan dan menyusun langkah selanjutnya. Warner \& Myers (2011) menjelaskan evaluasi memberi guru kesempatan untuk menilai pengetahuan siswa dan memberikan umpan balik kinerja. Penilaian dan umpan balik dibutuhkan untuk meyakinkan, mendorong, atau mengarahkan siswa.

\section{Guru Memberikan Tugas Proyek \\ Permasalahan yang harus} dijawab siswa dirancang dalam tugas terstruktur seperti membuat sebuah produk yang dapat menggambarkan pengetahuannya mengenai permasalahan yang sedang dipecahkan. Bentuk produk ini dapat berupa slide presentasi, grafik, poster, karangan, dan lain-lain. Temuan penelitian menunjukkan guru memberikan tugas proyek berkelompok. Siswa diperbolehkan mengerjakan tugas tersebut di luar kelas. Siswa juga diperkenankan bertanya pada ahli seperti dokter untuk menunjang laporan yang akan mereka susun sebagai tugas akhir dari guru.

Siswa dituntut untuk bekerja sama dan mengatur tugas anggota kelompok agar proyek dapat terlaksana. Wells (2001) menjelaskan pembelajaran inkuiri mengharuskan siswa untuk mengembangkan keterampilan manajemen diri dan organisasi untuk menyelesaikan studi. Selain itu siswa dituntut untuk melakukan penelitian, berbagi informasi, membuat keputusan, memecahkan masalah, menciptakan makna dan berkomunikasi dengan berbagai audiensi di dalam dan di luar kelas.

Keterlibatan siswa secara aktif merupakan konsep dasar pembelajaran inkuiri. Hal ini dapat dilakukan dengan memanfaatkan bermacam-macam 
sumber belajar, misalnya buku, website, televisi, wawancara dengan ahli, dan lain sebagainya. Siswa secara aktif untuk mengamati dan berinteraksi dengan orang dewasa dengan keahlian dan pengalaman yang relevan dalam berbagai situasi.

\section{Guru Membentuk Kelompok dalam Pembelajaran}

Siswa diminta bekerja dalam kelompok, dan mendiskusikan berbagai gagasan. Warner \& Myers (2011) menjelaskan penerapan pengetahuan baru ini memberikan kesempatan bagi siswa untuk melangkah lebih jauh untuk memahami yang lebih dalam tentang apa yang mereka telah mempelajari. Diskusi kelompok kecil dan ruang kelas terus memainkan peran penting dalam proses pembelajaran. Keadaan ini memungkinkan siswa untuk berbagi pemahaman dan penjelasan.

Pembentukan kelompok memudahkan guru memantau keaktifan dan peran siswa dalam lingkup kecil sebagai anggota kelompok. Kelompok belajar dibuat oleh guru agar siswa terlibat secara aktif. Blum \& Davis (2010) menjelaskan kegiatan kelompok mendorong pembimbing lebih fokus pada perilaku positif siswa, pembimbing dapat membantu seluruh siswa meraih sukses dalam pembelajaran dengan menggunakan strategi pemecahan masalah seperti mediasi untuk meredakan konflik. Pembelajaran dalam bentuk kelompok belajar dapat mengembangkan keterampilan siswa baik mengelola emosi dalam mengeluarkan pendapat dan mendengarkan pendapat. Membantu siswa belajar bersosialisasi dan menyesuaikan diri baik dalam berperilaku dan berpikir pada lingkungan kecil.

\section{Kesimpulan}

Inquiry learning adalah pendekatan pedagogis yang mengajak siswa untuk mengeksplorasi materi pelajaran dengan menyelidiki dan menjawab pertanyaan. Pembelajaran ini juga dapat disebut sebagai pembelajaran berbasis masalah. Siswa menjadi pusat dan harus aktif dalam pembelajaran agar dapat terampil melakukan penelitian, pengamatan, menganalisis dan membuat kesimpulan materi.

Beberapa temuan penelitian menunjukkan inquiry learning yang dilakukan oleh guru pada matapelajaran IPA antara lain: guru memulai pembelajaran dengan pertanyaan; guru mengarahkan siswa pada pemahaman yang mendalam; guru memberikan umpan balik; guru memberikan tugas proyek; guru membentuk kelompok dalam pembelajaran.

Perilaku yang dapat diamati dari siswa selama proses belajar pembelajaran dengan menggunakan metode pembelajaran inkuiri antara lain: tanggung jawab, kerja sama, ketelitian atau kecermatan, sikap percaya diri, sikap menghargai pendapat, mandiri dan terampil dalam memecahkan masalah.

\section{DAFTAR PUSTAKA}

Blum, D. J. \& Davis, T. E. 2010. The School Counselor's: Book of Lists, Secon Edition. San Francisco: Jossey-Bass.

Colburn, Alan. 2000. An Inquiry Primer. California: California State University Long Beach.

Creswell, J. W. 2012. Educational Research Planning, Conducting, and Evaluating Quantitative and Qualitative 
Research, Fourth Edition. Boston, Pearson.

Gysbers, N. C. \& Henderson, P. 2012. Developing and Managing Your School Guidance Program, Fifth Edition. Alexandria: American Counseling citationtion.

Kane, T. J., \& Cantrell, S. 2009. Measures of Effective Teaching (MET) Project: Learning about Teaching Initial Findings from the Measures of Effective Teaching Project. USA: The Bill \& Melinda Gates Foundation.

Kemendikbud. 2014. Peraturan Menteri Pendidikan dan Kebudayaan Republik Indonesia. Nomor 111 Tahun 2014 Tentang Bimbingan dan Konseling Pada Pendidikan Dasar dan Pendidikan Menengah. Jakarta: Menteri Pendidikan dan Kebudayaan Republik Indonesia.

Lai, Emily R. 2011. Motivation: A Literature Review, Research Report. New Jersey: Pearson.

Lodico, M. G., Spaulding, D. T., \& Voegtle, K. H. 2006. Methods In Educational Research From Theory to Practice. San Francisco: John Wiley \& Sons, Inc.
Mazzulla, Jan. 2011. Inquiry Based Learning. Curriculum Innovation and Applies Paper page 1-8.

Nelson, R. C. 1972. Guidance and Counseling in The Elementary School. USA: Holt, Rinehart, and Winston, Inc.

Santrock, J. W. 2011. Life-Span Development, Thirteenth Edition. New York: McGrawHill.

Slavin, R. E. 2012. Educational Psychology; Theory and Practice. New Jersey: Pearson.

Trusty, J., Mellin, E. A., \& Herbert, J. T. 2008. Closing Achievement Gaps: Roles and Tasks of Elementary School Counselors. The Elementary School Journal, Vol. 108 (5): 407-421.

Undang-Undang Republik Indonesia Nomor 14 Tahun 2005 Tentang Guru dan Dosen. Jakarta: Presiden Republik Indonesia.

Warner, Anna J. \& Myers, Brian E. 2011. Implementing InquiryBased Teaching Methods. Florida: University of Florida.

Wells, Gordon (2001). Action, talk \& text: Learning \& Teaching Through Inquiry. New York, NY: Teachers College Press. 